\title{
Spatial database for division of agricultural plots for the group of vegetableproducers
}

\author{
Anna Szeląg-Sikora ${ }^{1 *}$, Joanna Rorat $^{1}$ \\ ${ }^{1}$ University of Agriculture in Krakow, Faculty of Production and Power Engineering, ul. Balicka 116B, 30-149 Krakow, Poland
}

\begin{abstract}
Excessive fragmentation of agricultural enterprises is one of the most important barriers preventing the rational use of land in a large part of Poland. In particular, this problem affects the southeastern regions of the country. Proper spatial distribution of farmland is one of the most important factors enabling economical effectiveness of agricultural enterprises.

The purpose of the study was to create a spatial database which plotted the agricultural plots of a selected group of producers. The spatial database allowed determining the impact of the plots' location on the organization of field transport between the agricultural enterprise's head office and its plots.

The scope of study was a group of 5 vegetable producerslocated in Goczałkowice-Zdrój, in the commune of Goczałkowice-Zdrój, in the Pszczynapoviat, in the Śląskie Voivodeship.
\end{abstract}

\section{Introduction}

In recent years, agricultural production in Poland has developed, however, it still faces a number of problems.Its basic weakness is the unfavourable agrarian structure, which involves, among others, the high level of employment, low level of mechanization and low yield of marketable products of individual enterprises. Prevalent in Poland is small agricultural enterprises, with an area of up to 5 ha, which constitute $53.2 \%$ of thetotal. Enterprises ranging from 5 to 10 ha, which constitute $22 \%$, also have a significant share, on decrease in recent years. The largest enterprises, i.e. over 20 ha of agricultural land area, which have the largest development prospects, constitute only $9.4 \%$. The average area of an individual enterprise has slightly increased in recent years; in 2014, it was 10.48 ha [7]. Sill, this seems too small an area for a more effective use of the machine park, increased work efficiency and obtaining higher income. A prospective alternative may be to merge small, individual enterprises into groups, i.e. associations of producers, which allows them to jointly acquire and use machines, thus contributing to the improvement of labor productivity [8, 10]. Agricultural producer groups aim at supporting consortia of agricultural producers, so that, with a stronger position in relation to their customers, they can take over a part of the trade margin, and thus increase their income [9]. Excessive land fragmentation combined with a small area of plots, and also large distances from the enterprise's office often contribute to the abandonment of land use $[5,10]$.

The group activity of producers allows many benefits related to building a competitive advantage of an agricultural enterprise, not only at the point of selling their products, but also in terms of procurement and processing within the group [1]. Regardless of their size, individual enterprises are too small to be a partner of large entities involved in the agri-food brokerage and trade, and to meet the requirements of competitive agricultural producers associated in corporations. Small agricultural producers are often bound to a single buyer. This causes a lot of uncertainty as to the possibility of selling their products and meeting quality requirements. Joining efforts in a single, representative entity called the "agricultural producers' group" largely reduces this uncertainty, increases competitive power and ensures a more favourable position in relation tolarge commercial buyers and processors. In addition, it provides access to cheaper means of production and necessary services, as well as reduces the risk and uncertainty while maintaining the family character of agriculture $[3,4]$.

Created by agricultural producers for business purpose, groups adapt production to market demand by developing effective marketing structures, which enable the acquisition of product outlets both at home and abroad [6]. Producers may organize themselves into groupsin order to adapt the production to market conditions, improve management efficiency, plan production with particular emphasis on its quantity and quality, to concentrate supply and organize the sales of agricultural products, as well as to protect the environment $[2,11]$.

\section{Purpose and scope of study}

The purpose of the study was to create a spatial database, which determined the agricultural plots of a selected group of agricultural producers. This database was created using the spatial information systems technique in the ArcView environment. It contains thematic layers

Corresponding author: Anna.Szelag-Sikora@ur.krakow.pl 
related to the shape and size of agricultural plots and the road network of the studied area.

For the purposes of the analysis, individual enterprises that belong to the studied producer group were coded in letters: A, B, C, D and E, and will be presented in this way. Due to for the different labour intensity of individual crops, an analysis of individual enterprises in terms of crop structure was also carried out.
The studyinvolves an association of 5 vegetable producers.

\section{Findings}

The studied group of producers jointly manages 620 ha of agricultural land. It specialized in root vegetables, and its rotation crop is cereal, root and oil crops. The listed groups of plants accounted for $41 \%, 37 \%, 19 \%$ and $3 \%$ of the sowing structure respectively (Table 1).

Table 1. Area and structure of crops for the entire group and individual enterprises.

\begin{tabular}{|c|c|c|c|c|c|c|c|}
\hline Specification of crops & Group & $\begin{array}{c}\text { A } \\
\text { [ha] }\end{array}$ & $\begin{array}{c}\text { B } \\
{[\text { ha] }}\end{array}$ & $\begin{array}{c}\text { C } \\
{[\text { ha] }}\end{array}$ & $\begin{array}{c}\text { D } \\
\text { [ha] }\end{array}$ & $\begin{array}{c}\mathbf{E} \\
{[\mathrm{ha}]}\end{array}$ & $\begin{array}{c}\text { Structure } \\
{[\%]}\end{array}$ \\
\hline beetroot & 15 & 15 & & & & & 2 \\
\hline parsley & 20 & & & & 20 & & 3 \\
\hline spring barley & 9 & & & & & 9 & 2 \\
\hline maize & 24 & 24 & & & & & 4 \\
\hline carrot & 198 & 108 & 53.5 & 10 & & 26.5 & 32 \\
\hline cereal mixture & 8 & 3 & 4 & 1 & & & 1 \\
\hline spring wheat & 33.5 & 0 & 0 & & 17 & 16.5 & 5 \\
\hline winter wheat & 164 & 47 & 95 & & 19 & 3 & 27 \\
\hline potato & 118.5 & 51 & 21.5 & & 30 & 16 & 19 \\
\hline winter rape & 19 & 0 & 19 & & & & 3 \\
\hline oat & 9 & 0 & 0 & 9 & & & 2 \\
\hline TUZ & 2 & 1 & 1 & & & & 0 \\
\hline Total & 620 & 249 & 194 & 20 & 86 & 71 & 100 \\
\hline
\end{tabular}

The group's arable fields are located in 15 localities in three poviats of the Silesian Voivodship. The group, i.e. the associated producers own 1 field in 10 localities, these fields are respectively: $37,12,12,14,12,13,14$, 12,43 , and $7 \mathrm{~km}$ from the head office. Another 2 fields of two member producers are located in 1 village, $13 \mathrm{~km}$ from the head office. However, in 4 villages there are 3 fields belonging to 3 member producers, which are separated: $38,3,5,20 \mathrm{~km}$ from the headquarters respectively (Table 2).

Table 2. The area of the group's agricultural plots and enterprises A, B, C, D and E in individual localities.

\begin{tabular}{|c|c|c|c|c|c|c|c|}
\hline \multirow[b]{2}{*}{ Locality } & \multirow{2}{*}{$\begin{array}{c}\text { Distance } \\
\text { of fields from } \\
\text { the head office } \\
{[\mathrm{km}]}\end{array}$} & \multirow{2}{*}{$\begin{array}{c}\text { Area } \\
\text { of the group's } \\
\text { fields } \\
\text { [ha] }\end{array}$} & \multicolumn{5}{|c|}{$\begin{array}{c}\text { Areaof fields in individual enterprises } \\
\text { [ha] }\end{array}$} \\
\hline & & & $\mathbf{A}$ & B & $\mathbf{C}$ & D & $\mathbf{E}$ \\
\hline Bełk & 38 & 190.5 & & 120 & & 30 & 40.5 \\
\hline Czechowice-Dziedzice & 37 & 37 & & & & 37 & \\
\hline Ćwiklice & 12 & 14 & & & & & 14 \\
\hline Goczałkowice-Zdrój & 3 & 64 & 36 & 18 & 10 & & \\
\hline Kobielice & 12 & 10 & 10 & & & & \\
\hline Kryry & 14 & 9 & & & 9 & & \\
\hline Ligota & 12 & 24 & 24 & & & & \\
\hline Łąka & 5 & 65.5 & 48 & & 1 & & 16.5 \\
\hline Miedźna & 13 & 19.5 & & 19.5 & & & \\
\hline Międzyrzecze & 14 & 65 & 65 & & & & \\
\hline Poręba & 12 & 6 & 6 & & & & \\
\hline Stanowice & 43 & 2 & & 2 & & & \\
\hline StaraWieś & 7 & 18 & 18 & & & & \\
\hline Studzionka & 20 & 61.5 & 21 & 21.5 & & 19 & \\
\hline WisłaWielka & 13 & 34 & 21 & 13 & & & \\
\hline Total & & 620 & 249 & 194 & 20 & 86 & 71 \\
\hline
\end{tabular}

As mentioned above, the study covered agricultural enterprises associated in a vegetableproducers group, based in Goczałkowice, in the Pszczynapoviat, in southern Poland,consisting of 5 enterprises (Figure 1). 




Figure 1. The head office of the studied agricultural producers group.

A fragment of the spatial distribution of agricultural plots with displayed attributes is shown in Figure 2. The example shows the name of the agricultural plot that is unique in a given production year, displayed as the object label. In the created spatial database, this number is the identifying code (name of the object), based on which other attributes describing the spatial object (agricultural plot) can be combined. In this case, the image is non-editable and shows the surface area of the community in a geographical layout. On the other hand, polygons, which are the thematic layer of the agricultural plots, are fully editable in terms of the added attributes as well as the outline and shape.

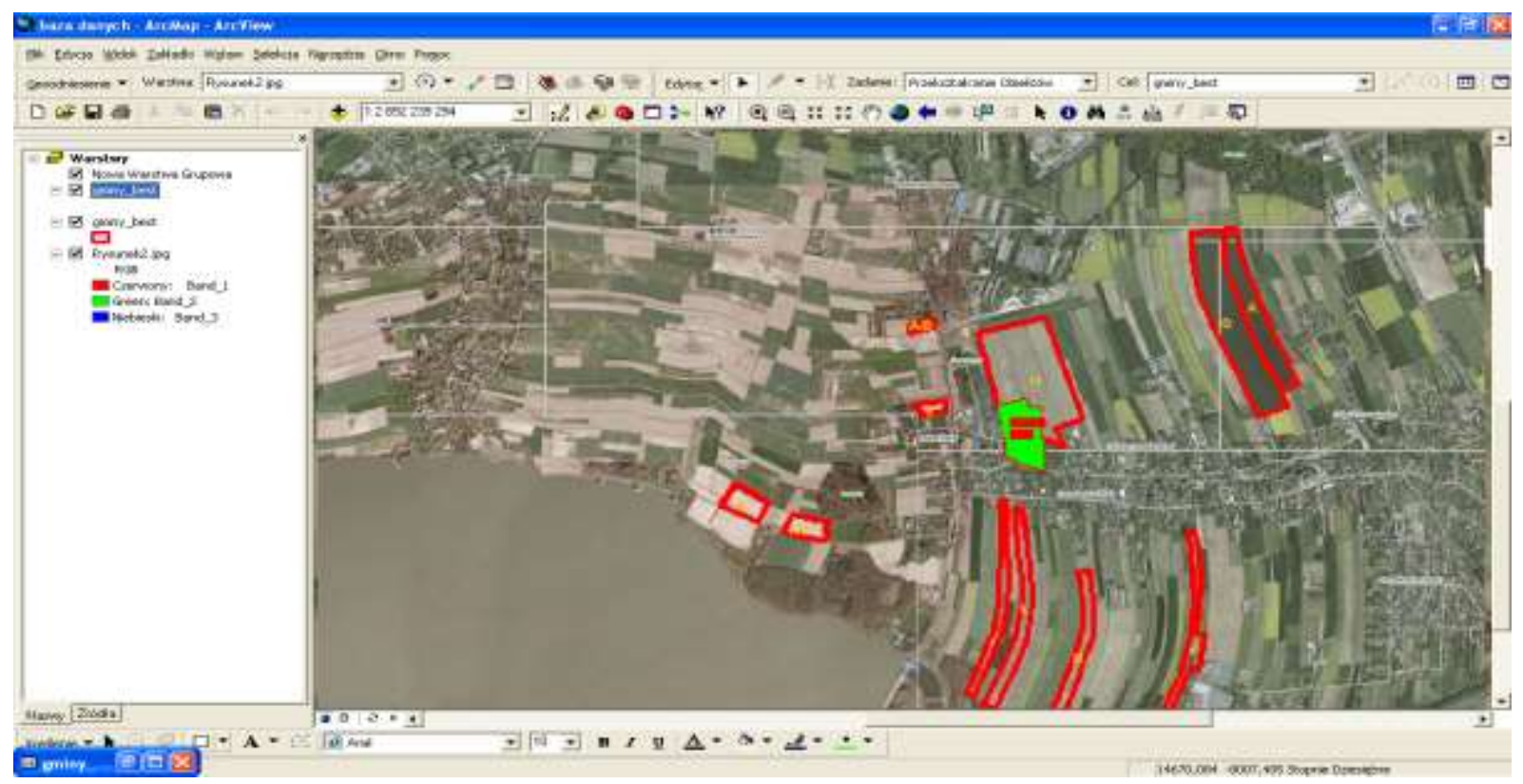

Figure 2. The distribution of the registration plots of the studied agricultural producers group was entered in the ArcView program.

The raster coverage of the producer group was prepared in the scale 1:10,000, which covers the area of the spatial layout of the studied enterprises. In the adopted scale, the area is $760 \times 320 \mathrm{~mm}$ and it would be difficult to use it in an analog format. With the non-scale feature of GIS systems, the analysis of such an area is done on the screen of a traditional computer. The area includes the plots of the enterprises; the image describing its characteristics was entered into the coordinate system. The system to which the raster substrate was adjusted is a commonly used WGS84. The orthophotomaps that producers receive from the Agency for Restructuring and Modernization of Agriculture (ARMiR) are in the 1992 system (this is the most commonly used reference system in Poland). In the ArcView environment, the migration between these two systems is done automatically. The attributes of the prepared polygonal thematic layer showing the distribution of plots can be added and modified in *.dbf format. 


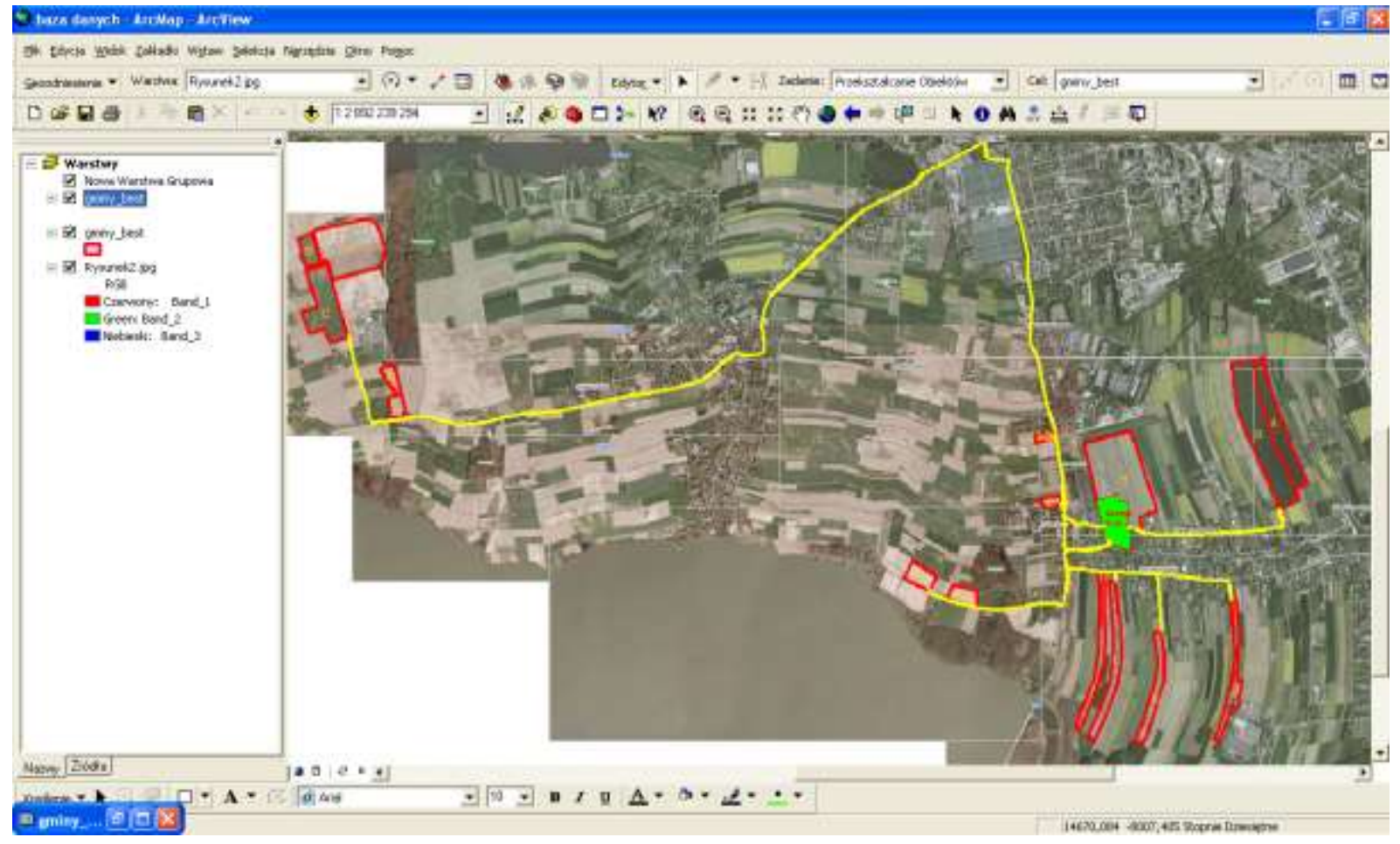

Figure 3. The distribution of the registration plots of the studied agricultural producers group with routes from the group's headquarters to the plot borders.

The prepared spatial database allows automatic exploration of the geographical image of plots with a vector layer depicting the access to the plot. This is shown in Figure 3. The spatial database automatic display of the distance between the head office and the plot. The largest distance of a plot from the head office of the group is $6.44 \mathrm{~km}$. However, the average distance from a plot to the producer group head office is $1.61 \mathrm{~km}$.

The spatial database made using the Spatial Information Systems can be successfully applied to the management of agricultural production as it facilitates creating graphic attachments. The database can be used successfully for archiving and inventory of the of parameters of agricultural production, which has a specific spatial character, easily used in the Spatial Information Systems.

\section{Summary and conclusions}

Creating an agricultural producers group contributed to a significant improvement in the spatial distribution of agricultural plots. The group manages a total of 620 hectares of arable land. Its area is over 83 times larger than the national average in the Śląskie Voivodship, which was 7.42 ha in 2015. By coming together, the group gained large agricultural plots in 15 localities and the fragmentation of cultivated crops was halved. The group is now more likely to receive assistance and investment funds, and has used this opportunity with the help of a consulting company. The machine park has been supplemented with specialized machines in line with the production direction. As a group,the producers have established their brand on the domestic and foreign market.

The study carried out in the entire agricultural producers group and in individual enterprises A, B, C, D and $\mathrm{E}$ made it possible to formulate the following conclusions:

1. Five producers are associated with the agricultural producers group selected for research. Enterprises A and $\mathrm{B}$ contributed to the largest percentage of agricultural land in the group, i.e. $40 \%$ and $31 \%$,respectively, while the remaining enterprises $\mathrm{C}, \mathrm{D}$ and $\mathrm{E}$ contributed 3\%, $14 \%$ and $12 \%$ respectively.

2. The GIS system environment can be appropriately used for the archiving, storage and visualization of agricultural production data on agricultural plots.

3. The prepared database allows determining the distance from the headquarters of the producer group automatically.

4. The agricultural producers group cultivates 620 ha of farmland, which is 124 ha per 1 producer on average. This area is over 17 times larger than the national average in the Śląskie Voivodship, which was 7.42 ha in 2013.

5. A group of agricultural producers grows 12 species of plants in 15 localities. However, when considering each of the enterprises separately, the number of cultivated plant species would be twice as large and would amount to 24 species grown in 24localities. The founding of an agricultural producers group contributed to the consolidation of agricultural plots. Thus, the area of individual fields increased and the number of crop species decreased by half.

6. Based on the archived attribute data, fertilization, yielding and protection of plants on individual 
agricultural plots can be analysed automatically in a tabular form and can serve as the basis for agrienvironmental reports requiring the knowledge about crop rotation and fertilization.

7. Together, it is easier for agricultural producers to invest. The group purchased specialized cultivation machines and a modern technological line for washing, polishing and packing vegetables, and built a new storage facility, which would be difficult to carry out individually.

8. The agricultural producers group specializes in the cultivation of root vegetables, especially carrots. In the structure of crops, vegetables occupy 233 ha, which constitutes $38 \%$ of the whole cultivation area, including $32 \%$ of carrots. Grain crops are grown on an area of 247.5 ha, i.e. $40 \%$ of the area, winter rape on 19 ha, i.e. $3 \%$ of the area, potatoes on 118.5 ha $-19 \%$ of the area; permanent grassland is 2 ha. On the other hand, carrot was grown in 4 individual enterprises, i.e. A, B, C and E. 9. Each of the enterprises declared that the integration with the European Union brought an increase in its area, as well as legalization of lease and improvement in the quality of their products.

10. The agricultural producers group declared that they used a broad range of services regarding consulting, maintenance and repair as well as building renovation.

11. The distribution and sale of agricultural products has been expanded. The sales market was expanded, among others, by export to Eastern Europe. Great emphasis was placed on marketing and advertising.

12. The owners of 4 enterprises are men and 1 is a woman. The average age of the associatedenterprise owners is 40 years.

13. The agricultural producer group uses the full extent of the services of a consulting company, which significantly allows the use of aid funds.

14. In production, great emphasis is placed on the high quality of produced crops.

\section{References}

1. Appel F., Ostetmeyer - Wiethaup A., Utilities Policy 41, (2016)

2. Czapiewska G. Acta Universitatis Lodziensis Folia Geographica Socio-Oeconomica, 13, 165-178, (2013)

3. Domagalska-Grędys M. Scientific Journal of Warsaw University of Life Science. Series G Agriculture Economics, Vol. 97, No. 4, Warsaw, 54-59, (2010)

4. Grzywińska-Rąpca M. Scientific Journal of Wrocław University of Economics, 264-268, (2003)

5. Janus J. Infrastruktura i ekologia terenów wiejskich, no. 2, 71-81, (2011)

6. Kowalski, S., Szeląg-Sikora A., Oleksy-Gębczyk, A. Inżynieria Rolnicza, 6 (131),101-108, (2011)

7. S. Nawar, R. Corstanje, G. Halcro, D. Mulla, A.M. Mouazen, Adv. in Agron. 175-244 (2017)
8. Statistical Yearbook of Agriculture in 2014, Warsaw. Download from: http://stat.gov.pl/obszarytematyczne/roczniki-statystyczne/rocznikistatystyczne/rocznik-statystyczny-rolnictwa2015,6,9.html on Oct. 10, 2016.

9. Tabor, S., Cupiał, M. Proceedings XXIX CIOSTA GIGR V Congress, Krakow, Poland, 25-27, 154157, (2001)

10. Rorat J., Szeląg-Sikora A. Inżynieria Rolnicza, 4 (148),133-142, (2013)

11. Sudduth K.A., Drummond S.T. Agron. J. 99:14711482 (2007) 